\author{
V.O. Dytiatkovsky ${ }^{1}$, \\ O.E. Abaturov ${ }^{1}$, \\ N.V. Naumenko ${ }^{2}$, \\ N.L. Pinayeva ${ }^{2}$, \\ O.O. Alifirenko ${ }^{2}$
}

\title{
ASSOCIATIONS OF GENOTYPE VARIANTS OF SINGLE NUCLEOTIDE POLYMORPHISM OF GENE OROSOMUCOID-1-LIKE-PROTEIN 3 AND ATOPIC DISEASES IN CHILDREN
}

\author{
SE «Dnipropetrovsk medical academy of Health Ministry of Ukraine» ${ }^{l}$ \\ Department of Pediatrics 1 and Medical Genetics \\ V. Vernadsky str., 9, Dnipro, 49044, Ukraine \\ MI "Dnipro clinical association of emergency medicine" Allergy Centre 2 \\ Shmidta str., 26, Dnipro, 49006, Ukraine \\ Д3 «Дніпропетровська медична академія МОЗ України» ${ }^{1}$ \\ кафедра педіатрії 1 та медичної генетики \\ (зав. - д. мед. н., проф. О.С. Абатуров) \\ вул В. Вернадського, 9, Дніпро, Україна \\ Алергологічний ичентр КЗ «ДКОШМД ДМР» ${ }^{2}$ \\ вул. Шмідта, 26, Дніпро, 49006, Україна \\ e-mail:ditiatkovskyvo@gmail.com
}

\author{
Цитування: Медичні перспективи. 2019. Т. 24, № 3. С. 67-73 \\ Cited: Medicni perspektivi. 2019;24(3):67-73
}

Key words: atopic diseases, children, genotype, associations, orsomucoid-1-like protein 3

Ключові слова: атопічні захворювання, діти, генотипи, асоиіації, орсомукоїд-1-подібнй білок 3

Ключевые слова: атопические заболевания, дети, генотипь, ассоциаџии, орсомукоид-1-подобный белок 3

\begin{abstract}
Associations of genotype variants of single nucleotide polymorphism of gene orosomucoid-1-like-protein 3 and atopic diseases at children. Dytiatkovsky V.O., Abaturov O.E., Naumenko N.V., Pinayeva N.L., Alifirenko O.O. The paper presents data of the firstly conducted in Ukraine own study of associations of the single nucleotide polymorphism (SNP) rs7216389 of orsomucoid-1-like protein 3 gene (ORMDL3) variants' with atopic diseases in children. Aim: to detect clinical significance of the SNP rs7216389 ORMDL3 in genesis of atopic diseases in children. We examined 153 children aged 3 to 18 years. The main group consisted of 119 children with clinical manifestations of atopic diseases with elevated total serum immunoglobulin E, confirmed by immunofluorescence assay method. The comparison group consisted of 34 children with a non-aggravated individual or family allergic anamnesis in whom there was detected the absence of any clinical syndromes and symptoms of atopic diseases and, mostly, physiological parameters of the serum total immunoglobulin E by immunofluorescence assay method. All the children were genotyped by ORMDL3 gene using polymerase chain reaction in real time with a restricted fragment length polymorphism. The genotype T/T within SNP rs7216389 of ORMDL3 gene significantly prevails among the children with atopic diseases and is associated with an increased incidence risk of seasonal allergic rhinoconjunctivitis (SARC) by 4.11 times (95\% CI 1.55; 16.61), perennial allergic rhinitis (PAR) by 5.07 times $(95 \%$ CI 1.22; 13.90) times and bronchial asthma (BA) by 10.31 times (95\% CI 2.50; 42.62). Children with genotype T/T in locus rs 7216389 of the ORMDL3 gene are the increased risk group for developing the atopic diseases. Children with genotype C/C in locus rs 7216389 of the ORMDL3 gene are the decreased risk group for the development of atopic dermatitis.
\end{abstract}

Реферат. Асоціації генотипових варіантів однонуклеотидного поліморфізму гена орсомукоїд-1-подібного білка 3 типу та атопічних захворювань дітей. Дитятковський В.О., Абатуров О.С., Науменко Н.В., Пінасва Н.Л., Аліфіренко О.О. У статті наведені дані вперше проведеного в Украӥні власного дослідження асочіацій однонуклеотидного поліморфізму (SNP) rs7216389 гена орсомукоїд-1-подібного білка 3 (ORMDL3) з атопічними захворюваннями в дітей. Мета: визначити клінічне значення SNP rs7216389 гена ORMDL3 в розвитку атопічних захворювань у дітей. Нами обстежено 153 дитини віком від 3 до 18 років. Основну групу представили 119 дітей з клінічними проявами атопічних захворювань та підвищеним рівнем загального сироваткового імуноглобуліну Е, підтвердженим методом імунофлюоресцетного аналізу. Групу порівняння склали 34 дитини з необтяженим індивідуальним чи сімейним алергологічним анамнезом, у яких була визначена відсутність будь-яких клінічних синдромів та симптомів атопічних захворювань. Усім дітям проведено генотипування гена ORMDL3 методом полімеразної ланцюгової реакиї в реальному часі з рестриктивним фрагментом довжини поліморфізму. Генотип T/T SNP rs7216389 гена ORMDL3 достовірно переважає серед дітей з атопічними захворюваннями та асоиійований з підвищеним ризиком захворюваності на сезонний 
алергічний ринокон'юктивіт у 4,11 раза (95\% ДІ 1.55;16.61), иілорічний алергічний риніт у 5,07 раза (95\% ДІ 1.22; 13.90) та бронхіальну астму в 10,31 раза (95\% ДІ 2.50; 42.62). Діти з генотипом Т/T SNP rs 7216389 гена ORMDL3 є групою підвищеного ризику розвитку атопічних захворювань.

In the world as a whole, and in Ukraine, in particular, there is being observed an increase incidenced of the atopic diseases (AtD) in childhood. Thus, according to data of the Ministry of Health of Ukraine, during 2009-2014 there is a gradual increase in the incidence of atopic dermatitis (AD) among children aged 0 to 18 years [1], which in turn is the first step of the so-called atopic march (AM) a linear transformation of $\mathrm{AD}$ into seasonal allergic rhinoconjunctivitis (SARC), perennial allergic rhinitis (CAR) and bronchial asthma (BA).

Single nucleotide polymorphisms (SNP) of genes involved in the pathogenesis of allergic inflammation have a primary significance among all the genetic factors of various AtD progression in children.

One of the central genes involved in the pathogenesis of AtD, namely, bronchial asthma (BA), is the ORMDL3 gene (orsomucoid-1-like protein 3 gene) that controls the synthesis of orosomucoid-1-like protein 3 or sphingolipid regulator of biosynthesis 3 .

The ORMDL3 gene with a total length of 6560 bps includes three exons and encodes a protein of 153 amino acids with four probable transmembrane domains that are fixed onto the endoplasmic reticulum $[2,11]$. The ORMDL3 gene is located in the chromosome 17q21 and belongs to the new ORM gene family, which plays an important role in the negative regulation of the sphingnolipid homeostasis which were studied on the example of Saccharomyces cerevisae yeast and helped Breslow et al. to establish an increased incline to pediatric asthma [10]. Region 17q21, which contains $O R M D L 3$ gene is specifically associated with the risk of pediatric BA [8].

Recently, it has been found that ORMDL3 protein changes the endoplasmic reticulum mediated by $\mathrm{Ca}^{2+}$-gomeostasis and facilitates up the deployed protein response that is considered to be an endogenous inflammatory inductor [12].

In a study by L. Akhabir et al. [3], it was demonstrated the strongest association of SNP's ORMDL3 gene with the risk of pediatric BA. Authors confirmed the hypothesis on the role of region $17 \mathrm{q} 21$ genes, particularly the ORMDL3 gene in the onset of BA. In a study by J.G. Ono et al. [9] it was pointed at direct association of SNP ORMDL3 with the pathogenesis of bronchial hyper-responsiveness, which reveals new diagnostic possibilities for BA.

According to the the meta-analysis results conducted by $\mathrm{H} \mathrm{Wu}$ et al. [6], large-scale genomewide association (GWAS) studies $[2,11] \mathrm{T}$ allele of
$O R M D L 3$ gene is associated with an increased risk of BA, especially in childhood [7]. In the H. Shi et al. meta-analysis [5] by the "case-control" model, the results of the study of 6462 patients with BA and 7357 controls in the control group were published. This analysis of age subgroups pointed at a statistically significant association of the risk of BA development in children with SNP rs7216389 of the $O R M D L 3$ gene.

The above studies enabled us to assume the decisive role of SNP rs7216389 in the ORMDL3 gene in the pathogenesis of AM. To confirm the chosen hypothesis, we conducted studying variants of SNP rs7216389 of ORMDL3 gene in children suffering from AM nosologies. The lack of data on the role of SNP rs7216389 in the ORMDL3 gene for Ukraine proves the reasonability of studying this SNP on local pediatric cohorts.

\section{MATERIALS AND METHODS OF RESEARCH}

We studied 119 children of the main group with AtD and 34 children of the comparison group aged from 3 to 18 years old. The study of children of the main group was conducted at the Department of Pediatrics 1 and Medical Genetics of the SE "Dnipropetrovsk Medical Academy of Health Ministry of Ukraine", based at MI "Dnipro City Clinical Hospital N 1 of the Dnipro City Council" and the pediatric department of the Allergy Center "Dnipro Clinical Association of Emergency Care Medicine of the Dnipro City Council". The study of the comparison group children was conducted at premises of the Department of pediatric gastroenterology of the MI "Dnipro Municipal Clinical Hospital N 1 of the Dnipro City Council". For each patient in the study group there was obtained an informed voluntary consent from the children's parents or their legal representatives for diagnostic intervention by means of the buccal swab from the oral cavity mucosa.

The inclusion criteria in the main group were: established diagnosis of AD, SARC, PAR and BA. The exclusion criteria were: not elevated total serum IgE level. Children from the comparison group were included in the study in the absence of a clinical picture of AtD at examination time, as well as without aggravated individual or family allergic history. The nosology structure of the comparison group included digestive system diseases (functional dyspepsia, gastroesophageal reflux disease, chronic gastritis, chronic gastroduodenitis, stomach and duodenal ulcer, functional disorders of the biliary system). 
All the children with AtD passed through a clinical examination using standardized diagnostic tools (SCORAD Index, asthma control test (ACT)). Atopy was confirmed by elevated levels of general and/or specific serum IgE to causative allergens revealed by the immunofluorescence assay in the certified laboratory of "Diagnostic Center of Medical Academy Pharmacies" Ltd.

All the patients were genotyped using standardized rs 7216389 TaqMan ${ }^{\circledR}$ assays by means of real time polymerase chain reaction with a restricted fragment length polymorphism (Real Time PCRRFLP). The genotyping was carried out on the Applied Biosystems 7500 Fast Real Time PCR
System [4] in a certified laboratory of the Department of General and Molecular Pathophysiology of the O.O. Bohomolets Institute of Physiology of the National Academy of Sciences of Ukraine.

The statistical analysis was performed using the Statistica v.6.1 package (Statsoft Inc., USA, license \# AGAR909E415822FA) and sensitive criteria: Fischer's exact test (FET), validated by the reliability p-test at the level of $p<0.05$ and the odds ratio (OR) with a $95 \%$ confidence interval $(\mathrm{CI})$.

\section{RESULTS AND DISCUSSION}

Incidence of definite AtD nosologies among the main group children is presented on figure 1 .

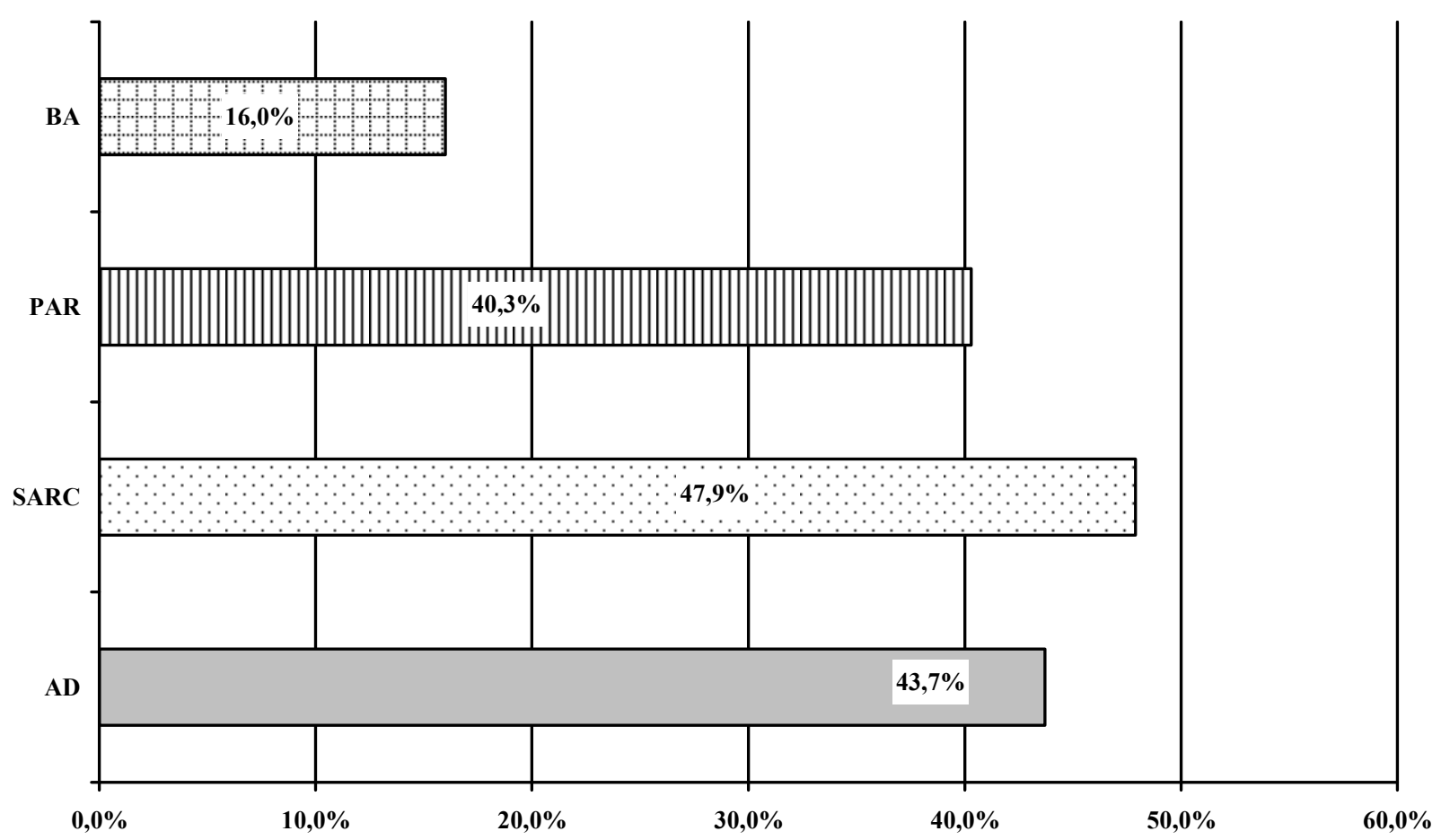

Fig. 1. Incidence of definite AtD in the main group

The frequency structure of different ORMDL3 gene SNP rs7216389 genotypes among children of the main and comparison groups, presented in Table 1, indicates the significant prevalence of $\mathrm{T} / \mathrm{T}$ genotype in children with AtD.

It is obviuos from Table 1 that the reliable risk of AtD onset or progression equals to 3.8 with $95 \% \mathrm{CI}$ (1.24; 11.63) given $\mathrm{T} / \mathrm{T}$ genotype of SNP rs7216389 ORMDL3 gene.

Atopic dermatitis.

The frequency of the studied genotypes in children with $\mathrm{AD}$ in the main group and in com- parison group evidences of a statistically significant prevalence of the $\mathrm{C} / \mathrm{C}$ genotype SNP rs7216389 of ORMDL3 gene among the children of comparison group (tab.2). Odds ratios for AD within different genotypes variants of the studied gene are shown. The risk of developing $\mathrm{AD}$ within genotype $\mathrm{C} / \mathrm{C}$ SNP rs7216389 ORMDL3 gene is significantly low and equals to 0.23 with $95 \% \mathrm{CI}(0.06 ; 0.84)$ in the carriers. The T/T genotype's OR for AD is 2.76 with $95 \%$ CI $(0.81$; 9.38), however, these data are not statistically significant (tab. 2) 
Table 1

Comparative characteristics of different genotypes of SNP rs7216389 ORMDL3 gene frequency in children of the main and comparison group

\begin{tabular}{|c|c|c|c|}
\hline \multirow{2}{*}{ Groups and statistic criteria } & \multicolumn{3}{|c|}{ Genotypes of SNP rs7216389 ORMDL3 gene } \\
\hline & $\mathrm{C} / \mathrm{C}$ & $\mathbf{C} / \mathbf{T}$ & $\mathbf{T} / \mathbf{T}$ \\
\hline Main group & $10.1 \%$ & $56.3 \%$ & $33.6 \%$ \\
\hline Comparison group & $26.5 \%$ & $61.8 \%$ & $11.8 \%$ \\
\hline Pearson Chi-square, p-level & $\mathbf{p}<0.05$ & $p>0.05$ & $\mathbf{p}<0.05$ \\
\hline Fisher exact, two-tailed, p-level & $\mathbf{p}<\mathbf{0 . 0 5}$ & $\mathrm{p}>0.05$ & $\mathbf{p}<\mathbf{0 . 0 5}$ \\
\hline Spearman Rank R, p-level & $\mathbf{p}<0.05$ & $p>0.05$ & $\mathbf{p}<\mathbf{0 . 0 5}$ \\
\hline Odds ratio (OR) & 0.31 & 0.80 & 3.8 \\
\hline$-95 \% ;+95 \%$ CI & $0.12 ; 0.83$ & $0.36 ; 1.75$ & $1.24 ; 11.63$ \\
\hline
\end{tabular}

Seasonal allergic rhinoconjunctivitis

The data on SNP rs7216389 genotypes of the ORMDL3 gene in children of the main group with SARC and comparison evidences that the highest statistically significant risk of SARC incidence is carried by the genotype T/T SNP rs7216389 ORMDL3 gene, which was detected in $40.4 \%$ of children and equaled to 5.07. The $\mathrm{C} / \mathrm{C}$ and $\mathrm{C} / \mathrm{T}$ genotypes are not significantly associated with the risk of developing SARC among the carriers (tab. 3).

Comparative characteristics of different genotypes of SNP rs7216389 ORMDL3 gene frequency in children of the main group with $A D$ and comparison group

\begin{tabular}{l|c|c|c}
\hline \multirow{2}{*}{ Groups and statistic criteria } & \multicolumn{3}{|c}{ Genotypes of SNP rs7216389 ORMDL3 gene } \\
\cline { 2 - 4 } & C/C & C/T & T/T \\
\hline Main group & $7.7 \%$ & $65.4 \%$ & $26.9 \%$ \\
Comparison group & $26.5 \%$ & $61.8 \%$ & $11.8 \%$ \\
FET, p-level & $p<0.05$ & $p>0.05$ & 2.05 \\
Odds ratio (OR) & 0.23 & 1.17 & 2.76 \\
$-95 \% ;+95 \%$ CI & $0.06 ; 0.84$ & $0.47 ; 2.91$ & $0.81 ; 9.38$ \\
\hline
\end{tabular}


Table 3

Comparative characteristics of different genotypes of SNP rs7216389 ORMDL3 gene frequency in children of the main group with SARC and comparison group

\begin{tabular}{l|c|c|c}
\hline \multirow{2}{*}{ Groups and statistic criteria } & \multicolumn{3}{|c}{ Genotypes of SNP rs7216389 ORMDL3 gene } \\
\cline { 2 - 4 } & $\mathrm{C} / \mathrm{C}$ & $\mathrm{C} / \mathrm{T}$ & $\mathrm{T} / \mathrm{T}$ \\
\hline Main group & $14.0 \%$ & $45.6 \%$ & $40.4 \%$ \\
Comparison group & $26.5 \%$ & $61.8 \%$ & $11.8 \%$ \\
FET, p-level & $\mathrm{p}>0.05$ & $\mathrm{p}>0.05$ & $\mathbf{p}<0.05$ \\
Odds ratio (OR) & 0.45 & 0.52 & 5.07 \\
\hline
\end{tabular}

\section{Perennial allergic rhinitis}

The frequency of different genotypes of SNP rs 7216389 of $O R M D L 3$ gene in children with PAR collated with the comparison group shows that $\mathrm{C} / \mathrm{C}$ genotype SNP rs7216389 of ORMDL3 gene is found to be significantly more seldom in PAR patients, compared to genotype $\mathrm{T} / \mathrm{T}$, including the comparison group. The true OR for PAR incidence among carriers of T/T genotype SNP rs7216389 of ORMDL3 gene is 4.11 times higher with $95 \% \mathrm{CI}$ $(1.22 ; 13.9)$ compared to those with the genotype C/C SNP rs7216389 of ORMDL3 gene (tab. 4).

Table 4

Comparative characteristics of different genotypes of SNP rs7216389 ORMDL3 gene frequency in children of the main group with PAR and comparison group

\begin{tabular}{l|c|c|c}
\hline \multirow{2}{*}{ Groups and statistic criteria } & \multicolumn{3}{|c}{ Genotypes of SNP rs7216389 ORMDL3 gene } \\
\cline { 2 - 4 } & C/C & C/T & T/T \\
\hline Main group & $8.3 \%$ & $56.3 \%$ & $35.4 \%$ \\
Comparison group & $26.5 \%$ & $61.8 \%$ & $11.8 \%$ \\
FET, p-level & $p<0.05$ & $p>0.05$ & 4.11 \\
Odds ratio (OR) & 0.25 & 0.80 & $1.22 ; 13.90$ \\
\hline
\end{tabular}

\section{Bronchial asthma}

The frequency of genotypes SNP rs7216389 of $O R M D L 3$ gene in children of the main group, suffering from BA collated to comparison group shows the significant prevalence of the $\mathrm{T} / \mathrm{T}$ variant SNP rs7216389 of ORMDL3 gene in children 
suffering from BA compared to a group of children without AtD (tab.5). The T/T genotype variant of SNP rs7216389 of ORMDL3 gene results in significantly 10.31 fold higher risk of developing $\mathrm{BA}$ in the carriers with $95 \%$ CI $(2.50 ; 42.62)$ compared to those possessing $\mathrm{C} / \mathrm{C}$ and $\mathrm{C} / \mathrm{T}$ genotype variants (tab. 5).

We detected the mostly incident nosologies in children of the main group: AD, SARC and PAR. In the framework of this study, for the first time in Ukraine we detected the frequency of $\mathrm{C}$ and $\mathrm{T}$ alleles of SNP rs7216389 of ORMDL3 gene in children with AtD. For the first time in Ukrainian pediatric groups, there was defined the frequency of carrying the $\mathrm{C} / \mathrm{C}, \mathrm{C} / \mathrm{T}$ and $\mathrm{T} / \mathrm{T}$ diploid alleles of $\mathrm{SNP}$ rs7216389 of ORMDL3 gene in AD, SARC, PAR and BA as well as in diseases of the digestive system.

Table 5

\begin{tabular}{|c|c|c|c|}
\hline \multirow{2}{*}{ Groups and statistic criteria } & \multicolumn{3}{|c|}{ Genotypes of SNP rs7216389 ORMDL3 gene } \\
\hline & $\mathrm{C} / \mathrm{C}$ & $\mathbf{C} / \mathbf{T}$ & $\mathbf{T} / \mathbf{T}$ \\
\hline Main group & $5.3 \%$ & $36.8 \%$ & $57.9 \%$ \\
\hline Comparison group & $26.5 \%$ & $61.8 \%$ & $11.8 \%$ \\
\hline FET, p-level & $\mathbf{p}>\mathbf{0 . 0 5}$ & $\mathbf{p}>\mathbf{0 . 0 5}$ & $\mathbf{p}<\mathbf{0 . 0 5}$ \\
\hline Odds ratio (OR) & 0.15 & 0.36 & 10.31 \\
\hline$-95 \% ;+95 \%$ CI & $0.02 ; 1.4$ & $0.11 ; 1.19$ & $2.50 ; 42.62$ \\
\hline
\end{tabular}

Analysis of the data obtained allows us to state the opposite biological effects of the $\mathrm{C} / \mathrm{C}$ and $\mathrm{T} / \mathrm{T}$ genotypes of SNP rs7216389 of ORMDL3 gene. Thus, the T/T variant was significantly more common in children with AtD than in children of comparison group with GIT pathology: in SARC and PAR - more than 3 times, in BA - almost 5 times. On the contrary, the $\mathrm{C} / \mathrm{C}$ variant was detected 3 times less than in children with pathology of the GIT.

The above findings made it possible to establish a homozygous $\mathrm{T} / \mathrm{T}$ variant as mostly associated with a significantly increased risk of AtD in general, as well as of its definite nosologies: SARC, PAR and $\mathrm{BA}-$ at 5.7, 4.11 and 10.31 fold, respectively.

At the same time, we determined that the $\mathrm{C} / \mathrm{C}$ genotype of SNP rs7216389 of ORMDL3 gene had an opposite biological effect - the carriers face a significantly low OR -0.23 - for developing the AD and potential transformation into BA. ORMDL3 gene SNP rs7216389 variant $\mathrm{C} / \mathrm{T}$ did not reveal significant associations with AtD in children. The latest finding indicates the need for further studies on larger pediatric groups to obtain statistically significant results for the $\mathrm{C} / \mathrm{T}$ variant as either a marker or a protector for the incline to AtD at children.

\section{CONCLUSIONS}

1. The T/T genotype of SNP rs7216389 of ORMDL3 gene in children is significantly associated with AtD, such as SARC, PAR and BA. The risk (OR) for SARC, PAR and BA in children with the T/T genotype of SNP rs7216389 of ORMDL3 gene equals to $5.07,4.11$ and 10.31 respectively. The C/C genotype SNP rs7216389 of ORMDL3 gene has a statistically significant association with the decreased risk of AtD incidence.

2. The T/T genotype of SNP rs7216389 of ORMDL3 gene can be used as the novel laboratory marker for genetic predisposition to both BA and other AtD progression at children.

\section{REFERENCES}

1. Dytyitakovsky VO. [Novel biochemical markers of atopic march at children]. Topical issues and practical aspects of pediatric pulmonology and allergology: standards of care. Conference. Dnipro: 2019;11. Ukrainian 
2. Moffatt MF, Gut IG, Demenais F, Strachan DP, Bouzigon E, Heath S, et al. A large-scale, consortiumbased genomewide association study of asthma. N Engl J Med. 2010;363(13):1211-21.

doi: https://doi.org/10.1056/nejmoa0906312

3. Akhabir L, Sandford AJ. Genome-wide association studies for discovery of genes involved in asthma. Respirology. $2011 \mathrm{Apr}$; 16(3):396-406. doi: https://doi.org/10.1111/j.1440-1843.2011.01939.x

4. Applied Biosystems 7500/7500 Fast Real Time PCR System. Genotyping experiments. Getting started guide. Applied Biosystems; 2010 Available from: https://assets.thermofisher.com/TFS-

Assets/LSG/manuals/4387784c.pdf

5. Shi H, Cheng D, Yi L, Huo X, Zhang K, Zhen G. Association between ORMDL3 polymorphism and susceptibility to asthma: a meta-analysis. Int $\mathrm{J}$ Clin Exp Med. 2015;8(3):3173-83. 2015 Mar 15. PMID: 26064206.

6. Wu H, Romieu I, Sienra-Monge JJ, Li H, del RioNavarro BE, London SJ. Genetic variation in ORM1like 3 (ORMDL3) and gasdermin-like (GSDML) and childhood asthma. Allergy. 2009;64(4):629-35. doi: https://doi.org/10.1111/j.1398-9995.2008.01912.x

7. Moffatt MF, Kabesch M, Liang L, Dixon AL, Strachan D, et al. Genetic variants regulating ORMDL3 expression contribute to the risk of childhood asthma. Nature. 2007;448(7152):470-5. doi: http://dx.doi.org/10.1038/nature06014

8. Ober C, Yao TC. The genetics of asthma and allergic disease: a 21st century perspective. Immunol Rev. 2011;242(1):10-30. doi: https://doi.org/10.1111/j.1600065x.2011.01029.x

9. Ono JG, Worgall TS, Worgall S. 17q21 locus and ORMDL3: an increased risk for childhood asthma. Pediatr Res. 2014 Jan;75(1-2):165-70.

doi: https://doi.org/10.1038/pr.2013.186

10. Breslow DK, Collins SR, Bodenmiller B, Aebersold R, Simons K, Shevchenko A, et al. Orm family proteins mediate sphingolipid homeostasis. Nature. 2010;463(7284):1048-53.

doi: https://doi.org/10.1038/nature08787

11. Galanter J, Choudhry S, Eng C, Nazario S, Rodríguez-Santana JR, CasalJ, Torres-PalaciosA, et al. ORMDL3 gene is associated with asthma in three ethnically diverse populations.Am J Respir Crit Care Med. 2008;177(11):1194-200.

doi: https://doi.org/10.1164/rccm.200711-1644oc

12. Cantero-Recasens G, Fandos C, Rubio-Moscardo F, Valverde MA, Vicente R. The asthma-associated ORMDL3 gene product regulates endoplasmic reticulummediated calcium signaling and cellular stress, Human Molecular Genetics. 2010 Jan 1;19(1):111-21. doi: https://doi.org/10.1093/hmg/ddp471

\section{СПИСОК ЛІТЕРАТУРИ}

1. Дитятковський В. О. Новітні біохімічні маркери атопічного дерматиту у дітей. Актуальні питання та практичні аспекти дитячої пульмонологї та алергологї: стандарти медичної допомоги: матеріали наук.-практ. конф. 3 міжнар. участю. Дніпро, 2019. С. 11.

2. A large-scale, consortium-based genomewide association study of asthma / M. F. Moffatt et al. N Engl. J. Med. 2010. Vol. 363, No. 13. P. 1211-1221. DOI: doi: https://doi.org/10.1056/nejmoa0906312

3. Akhabir L, Sandford AJ. Genome-wide association studies for discovery of genes involved in asthma. Respirology. 2011. Apr. (Vol. 16, No. 3). P. 396-406. DOI: https://doi.org/10.1111/j.1440-1843.2011.01939.x

4. Applied Biosystems 7500/7500 Fast Real Time PCR System. Genotyping experiments. Getting started guide. Applied Biosystems. 2010. https://assets.thermofisher.com/TFS-

Assets/LSG/manuals/4387784c.pdf

5. Association between ORMDL3 polymorphism and susceptibility to asthma: a meta-analysis / H. Shi et al. Int. J. Clin. Exp. Med. 2015. Vol. 8, No. 3. P. 3173-3183. Published 2015 Mar 15. PMID: 26064206.

6. Genetic variation in ORM1-like 3 (ORMDL3) and gasdermin-like (GSDML) and childhood asthma / H. Wu et al. Allergy. 2009. Vol. 64, No. 4. P. 629-635. DOI: https://doi.org/10.1111/j.1398-9995.2008.01912.x
7. Genetic variants regulating ORMDL3 expression contribute to the risk of childhood asthma / M. F. Moffatt et al. Nature. 2007. Vol. 448, No. 7152. P. 470-475. DOI: http://dx.doi.org/10.1038/nature06014

8. Ober C., Yao T. C. The genetics of asthma and allergic disease: a 21 st century perspective. Immunol Rev. 2011. Vol. 242, No. 1. P. 10-30.

DOI: https://doi.org/10.1111/j.1600-065x.2011.01029.x

9. Ono J. G., Worgall T. S., Worgall S. 17q21 locus and ORMDL3: an increased risk for childhood asthma. Pediatr Res. 2014. Jan. (Vol. 75, No. 1-2). P. 165-170. DOI: https://doi.org/10.1038/pr.2013.186

10. Orm family proteins mediate sphingolipid homeostasis / D. K. Breslow et al. Nature. 2010. Vol. 463, No. 7284. P. 1048-1053.

DOI: https://doi.org/10.1038/nature08787

11. ORMDL3 gene is associated with asthma in three ethnically diverse populations / J. Galanter et al. Am. J. Respir. Crit Care Med. 2008. Vol. 177, No. 11. P. 11941200. DOI: https://doi.org/10.1164/rccm.200711-1644oc

12. The asthma-associated ORMDL3 gene product regulates endoplasmic reticulum-mediated calcium signaling and cellular stress / G. Cantero-Recasens et al. Human Molecular Genetics. 2010. 1 Jan. (Vol. 19, Issue 1). P. 111-121, DOI: https://doi.org/10.1093/hmg/ddp471

Стаття надійшла до редакції 01.07 .2019 